Diabetologia 10, 145-148 (1974)

(C) by Springer-Verlag 1974

\title{
Role of the Kidneys in Hyperglycemia Provoked by Anti-Insulin Serum in Rats* **
}

\author{
P. B. Iynedjian and G. Peters \\ Institut de Pharmacologie de l'Université de Lausanne, Lausanne, Switzerland \\ Received: August 24, 1973, and in revised form: December 14, 1973
}

Summary. The hyperglycemic response to two 2-ml injections of guinea pig anti-insulin serum (GPAIS), given at a $1.5 \mathrm{~h}$ interval, was measured after $18 \mathrm{~h}$ of fast in nephrectomized rats, intact animals and animals with anuria caused by ligating the ureters. In controls plasma glucose rose by $+196+4.0 \mathrm{mg} / 100 \mathrm{ml}$ within $1.5 \mathrm{~h}$ after GPAIS injection, then levelled off with the onset of glucosuria and began to decline at $4.5 \mathrm{~h}$. Anuria due to ureteral obstruction did not affect the initial rise of plasma glucose $(+197 \pm 11.9 \mathrm{mg} / 100 \mathrm{ml}$ at $1.5 \mathrm{~h})$. In contrast, the initial rise of plasma glucose amounted to only
$+136 \pm 5.3 \mathrm{mg} / 100 \mathrm{ml}$ at $1.5 \mathrm{~h}$ in nephrectomized rats. Blood sugar remained lower in the latter animals than in those with ligated ureters for the rest of the experiment. The blunted glycemic response to GPAIS in anephric rats, thus, is due to the loss of kidney tissue per se. It is suggested that, after sudden insulin deprivation, the kidneys might release sizeable amounts of newly synthesized glucose into the circulation.

Key words: Anti-insulin serum, hyperglycemia, kidney, renal gluconeogenesis, nephrectomy, anuria.
The gluconeogenic capacity of the mammalian renal cortex has been extensively studied with cortical slices [17], isolated perfused kidneys [20], or suspensions of isolated nephron segments [19] from rats. While in these in vitro preparations the rate of glucose production per unit tissue weight is equal or superior to that of the isolated perfused liver [9], the bearing of renal gluconeogenesis on blood glucose homeostasis in the intact animal is still uncertain.

An indirect approach to the problem has been provided by studying the influence of nephrectomy on the development of evisceration hypoglycema or of diabetic hyperglycemia. It was shown that nephrectomized-eviscerated rats rapidly develop fatal hypoglycemia while non-nephrectomized controls maintain blood sugar levels compatible with life for many hours after operation [26]. Similarly the rapid fall of blood sugar after total evisceration of alloxan-diabetic rats is largely prevented if the kidneys are left untouched during evisceration [32]. We previously reported that nephrectomized rats fail to reach hyperglycemia comparable to that of controls in response to the diabetogenic drug $\mathrm{N}$-monomethylacetamide [13]. These data have been interpreted to mean that the kidney of the rat releases substantial amounts of glucose into the circulation.

In an attempt to delineate further the role of the kidney in regulating blood glucose in diabetic conditions, we studied the hyperglycemic response of nephrectomized rats to the administration of guinea pig anti-insulin serum (GPAIS). The blood glucose rise was compared to that in a control group of intact animals and in a group of animals with acute anuria caused by ligation of the ureters.

* Supported by Fonds National Suisse de la Recherche Scientifique, grant 3.370 .70 .

* Preliminary communication: Iynedjian and Peters, 1971 [14].

\section{Materials and Methods}

\section{Preparation of Guinea Pig Anti-Insulin Serum ( $G P A I S)$}

Antibodies to insulin were raised in guinea pigs by monthly injections of commercial porcine insulin solution (Actrapid ${ }^{\circledR}$, Novo Industri, Copenhagen; kindly supplied by Dr. L.C. Sangrouber) emulsified with Freund's adjuvant (Difco Lab., Detroit), complete for the first inoculation and incomplete for subsequent booster injections. As proposed by Wright et al. [36] hemophilus pertussis vaccine (Institut Sérothérapique et Vaccinal Suisse, Berne) was occassionally incorporated into the emulsion. After at least four subcutaneous $2 \mathrm{ml}$ injections (5 $\mathrm{U}$ insulin per $\mathrm{ml}$ ) blood was obtained from groups of guinea pigs by cardiac puncture under light ether anesthesia. The sera were pooled and stored at $-80^{\circ} \mathrm{C}$. The potency of each lot of serum was evaluated by measuring the rise of blood sugar induced by i.v. injection of $0.5 \mathrm{ml}$ aliquots in conscious fed rats. The hyperglycemic responses were equated to amounts of insulin neutralized by reference to the standard curves published by Robinson and Wright [27]. Two lots of serum, neutralizing between 0.9 and $1.8 \mathrm{U}$ insulin per $\mathrm{ml}$ of serum, were used in the subsequent experiments.

\section{Experimental Design}

Male Wistar type rats weighing $180-250 \mathrm{~g}$ were used. After $15 \mathrm{~h}$ of fasting they were randomly assigned to three groups and were submitted to nephrectomy, ligation of the ureters or sham-operation. The animals were allowed to recover for $3 \mathrm{~h}$ and were then injected with $2 \mathrm{ml}$ of GPAIS. A second $2 \mathrm{ml}$ injection of GPAIS was given $1.5 \mathrm{~h}$ later. Blood was collected immediately before the first injection and at selected intervals up to $4.5 \mathrm{~h}$ thereafter. Injections were administered to, and blood was obtained from, con- 
scious rats through indwelling aortic catheters implanted on the day before each experiment by the technique of Popovic and Popovic [23]. Plasma glucose was measured by a glucose-oxidase method [12].

\section{Results}

The time-course of hyperglycemia after GPAIS injections in intact controls, in rats with ureteral obstruction and in nephrectomized rats is illustrated in Fig. 1.

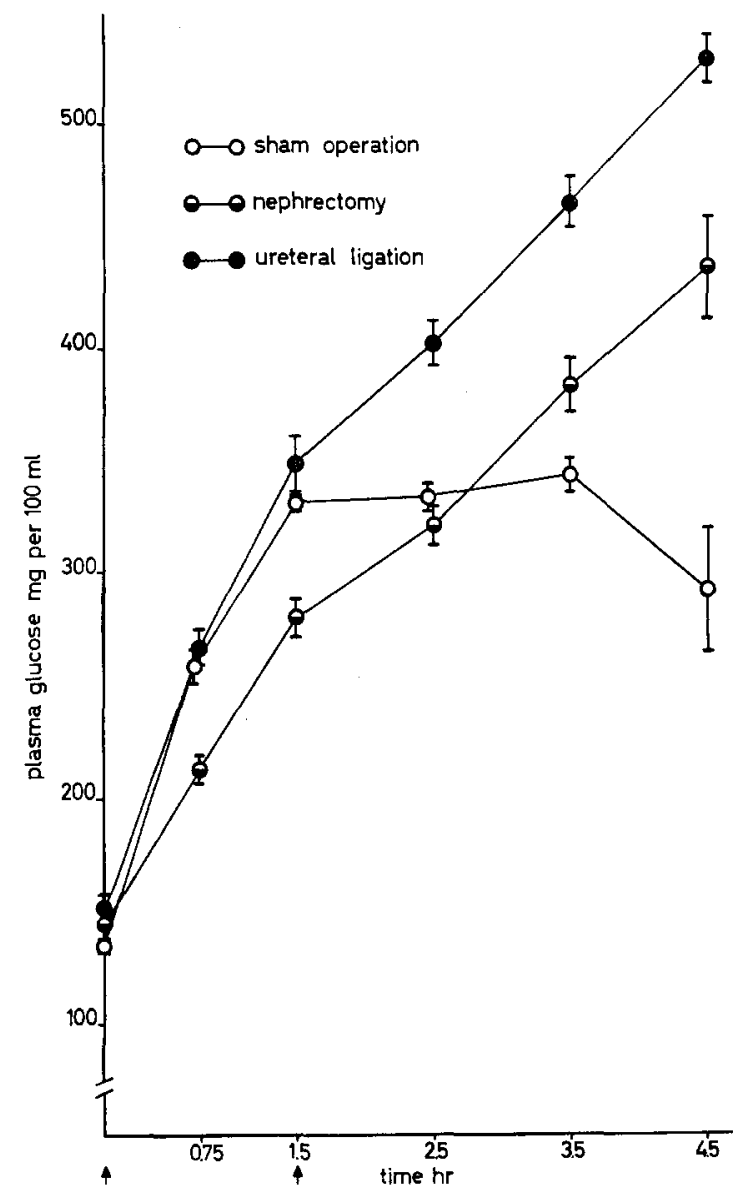

Fig. 1. Time-course of hyperglycemia after GPAIS injection in anephric, anuric and control rats. Food was withdrawn from the rats $18 \mathrm{~h}$ before the experiment. Nephrectomy, ureteral ligation or sham-operation were performed under ether anesthesia $3 \mathrm{~h}$ before the experiment. There were seven nephrectomized rats, seven rats with ureteral ligature and six intact controls. Arrows indicate times of injections of guinea pig anti-insulin serum. Results are given as means \pm SEM

In controls plasma glucose rose sharply by $196 \pm$ $4.0 \mathrm{mg} / 100 \mathrm{ml}$ within $1.5 \mathrm{~h}$ to reach a plateau lasting until $3.5 \mathrm{~h}$. Then, presumably with the reappearance of unneutralized insulin, blood glucose began to decline towards its normal value. The magnitude of the blood sugar response to GPAIS injections was similar to that observed by others using potent anti-sera $[2,3,10]$. Glucose appeared in the urine of most rats at $1.5 \mathrm{~h}$ and massive glucosuria ( $>2 \%$ as estimated by Tes-Tape, E. Lilly and Co., Indianapolis) was uniformly found at $2.5 \mathrm{~h}$.

Acute anuria provoked by tying off the ureters did not affect the initial rate of rise of plasma glucose $(197 \pm 11.9 \mathrm{mg} / 100 \mathrm{ml}$ in $1.5 \mathrm{~h})$. Whereas the plasma glucose concentration of intact rats stabilized at $1.5 \mathrm{~h}$ when the animals began to spill glucose in the urine, plasma glucose continued to rise until the end of the experiment in the anuric rats.

In contrast, the anephric state was characterized by a blunted blood sugar response to GPAIS. In the nephrectomized rats the initial rise of plasma glucose $(136 \pm 5.3 \mathrm{mg} / 100 \mathrm{ml}$ at $1.5 \mathrm{~h})$ was smaller than in either intact or anuric controls $(p<0.001)$. Furthermore, throughout the whole experiment the nephrectomized animals exhibited lower plasma glucose levels than animals made anuric by tying off the ureters.

\section{Discussion}

The rise of plasma glucose in reponse to acute insulin deficiency induced by GPAIS was impaired in anephric rats. As demonstrated by the experiments in animals with anuria due to ureteral ligation, this effect can be ascribed to the loss of renal tissue per se rather than to acute uremia.

The depressed hyperglycemic response in anephric rats may reflect curtailed endogenous glucose production and/or a higher rate of peripheral glucose utilization.

The kidney is a major site of insulin degradation [31], extracting about $40 \%$ of the insulin carried by the renal arterial blood $[5,16,24,25]$. It may therefore be expected that nephrectomy result in insulin sparing. In turn, the insulin spared might enhance peripheral glucose uptake. Actually, increased plasma levels of immunoreactive insulin were found in acutely nephrectomized rats [21] and dogs [33]. However, in the present experiments the anephric state lasted only a few hours and any insulin escaping renal degradation during this period was to be neutralized by antibodies injected in excess. In addition, both acute [18] and chronic $[4,11,34]$ renal failure are known to be associated with deterioration rather than improvement of the glucose tolerance. There is thus no obvious reason to believe that the depressed glycemic response to GPAIS in the anephric rats was due to improved glucose utilization.

More likely, the slower rise of plasma glucose in anephric rats resulted from reduced glucose input into the blood. Total [28] or partial [7] nephrectomy were reported to impair the capacity of the rat liver for glycogen deposition. The inability of the liver to maintain adequate glycogen stores was considered as the 
reason for the abnormally small blood sugar response to glucagon in patients with chronic renal failure [7]. A similar explanation does probably not apply to the present findings because the rats were fasted for $18 \mathrm{~h}$ before the experiments; hepatic glycogenolysis, therefore, contributed little to the hyperglycemic response even in intact animals.

An important fraction of the glucose released into the blood after injection of GPAIS must have originated from gluconeogenesis.

The depressed hyperglycemic response to GPAIS after nephrectomy, thus, probably reflects a depressed rate of gluconeogenesis, either due to the loss of the renal contribution to the overall rate of the formation of glucose or to a depressed rate of hepatic gluconeogenesis in the nephrectomized animal. Hepatic gluconeogenesis does not normally proceed at saturating substrate levels; hepatic gluconeogenesis could, therefore, be slowed down by a fall of the plasma concentration of substrates such as lactate, pyruvate or glucogenic amino acids. The plasma concentrations of these substances were not measured in the present experiments. Nephrectomy, however, cannot be expected to depress the plasma concentrations of these glucogenic substrates. Furthermore, any depression of hepatic gluconeogenesis by the uremic state should have resulted in an equal depression of the hyperglycemic response in nephrectomized animals and in rats with ligated ureters: in the latter group of animals the hyperglycemic response to GPAIS was not depressed.

Jefferson et al. demonstrated accelerated gluconeogenesis in isolated perfused livers taken from rats $1 \mathrm{~h}$ after injecting GPAIS [15]. In freeze-clamped rat livers, Williamson observed a pattern of metabolic intermediates indicative of favored gluconeogenesis as early as $30 \mathrm{~min}$ after GPAIS [35]. The present data suggest that renal gluconeogenesis may also increase and possibly contribute a substantial amount of glucose to the organism in a state of acute insulin deficiency.

Several recent studies in the dog have denied net glucose production by the kidney in situ [6, 8, 29, 30]. These studies do not exclude the possibility of sizeable renal glucose output in other species, especially under gluconeogenic conditions like diabetes. Indeed, a significant in vivo glucose production by the kidney was detected in human subjects with respiratory acidosis [1] and after prolonged starvation [22].

Acknowledgements. The technical assistance of Miss Lise Auberson is gratefully acknowledged.

\section{References}

1. Aber, G.M., Morris, L.O., Housley, E.: Gluconeogenesis by the human kidney. Nature (Lond.) 212, $1589-1590(1966)$

2. Anderson, J.W., Kilbourn, K.G., Robịnson, J.,
Wright, P.H.: Diabetic acidosis in rats treated with anti-insulin serum. Clin. Sci. 24, 417-430 (1963)

3. Armin, J., Grant, R.T., Wright, P.H.: Acute insulin deficiency provoked by single injection of antiinsulin serum. J. Physiol. (Lond.) 153, 131-145 (1960)

4. Cerletty, J.M., Engbring, N.H.: Azotemia and glucose intolerance. Ann. int. Med. 66, 1097-1108 (1967)

5. Chamberlain, M.J., Stimmler, L.: The renal handling of insulin. J. clin. Invest. 46, 911-919 (1967)

6. Churchill, P.C., Malvin, R.L.: Relation of renal gluconeogenesis to ammonia production in the dog. Amer. J. Physiol. 218, 241-245 (1970)

7. Cohen, B.D.: Abnormal carbohydrate metabolism in renal disease. Blood glucose unresponsiveness to hypoglycemia, epinephrine and glucagon. Ann. int. Med. 57, 204-213 (1962)

8. Costello, J., Scott, J.M., Wilson, P., Bourke, E.: Glucose utilization and production by the dog kidney in vivo in metabolic acidosis and alkalosis. J. clin. Invest. 52, 608-611 (1973)

9. Exton, J.H., Park, C.R.: Control of gluconeogenesis. I. General features of gluconeogenesis in the perfused liver of rats. J. biol. Chem. 242, 2622-2636 (1967)

10. Gregor, W.H., Martin, J.M., Williamson, J.R., Lacy, P.E., Kipnis, D.M. : A study of the diabetic syndrome produced in rats by antiinsulin serum. Diabetes 12, $73-81(1963)$

11. Hampers, C.L., Soeldner, J.S., Doak, P.B., Merrill, J.P.: Effect of chronic renal failure and hemodialysis on carbohydrate metabolism. J. clin. Invest. 45, $1719-1731(1966)$

12. Huggett, A.St.G., Nixon, D.A.: Use of glucose oxidase, peroxidase and o-dianisidine in determination of blood and urinary glucose. Lancet 1957 II, 368-370

13. Iynodjian, P.B.: Possible contribution of renal gluconeogenesis to the development of $\mathrm{N}$-monomethylacetamide-induced hyperglycemia in the rat. Diabetologia 9, 130-134 (1973)

14. Iynedjian, P.B., Peters, G.: Effects of acute insulin deficiency in nephrectomized rats. Proc. of the International Union of Physiolog'ical Sciences. Vol. IX. p. 274, abstract nr. 808. 25th International Congress Munich 1971

15. Jefferson, L.S., Exton, J.H., Butcher, R.W., Sutherland, E.W., Park, C.R.: Role of adenosine $3^{\prime}, 5^{\prime}$-monophosphate in the effects of insulin and anti-insulin serum on liver metabolism. J. biol. Chem. 243, 10311038 (1968)

16. Katz, A.I., Rubenstein, A.H.: Metabolism of proinsulin, insulin, and $\mathrm{C}$-peptide in the rat. J. clin. Invest. 52, 1113-1121 (1973)

17. Krebs, H.A., Bennett, D.A.H., de Gasquet, P., Gascoyne, T., Yoshida, T.: Renal gluconeogenesis. The effect of diet on the gluconeogenic capacity of rat.kidney-cortex slices. Biochem. J. 86, 22-27 (1963)

18. Kokot, F., Kuska, J.: Influence of extracorporeal dialysis on glucose utilization and insulin secretion in patients with acute renal failure. Europ. J. clin. Invest. 3, 105-111 (1973)

19. Nagata, N., Rasmussen, H.: Renal gluconeogenesis: effects of $\mathrm{Ca}^{2+}$ and $\mathrm{H}^{+}$. Biochim. biophys. Acta (Amst.) 215, 1-16 (1970)

20. Nishiitsutsuji-Uwo, J.M., Ross, B.D., Krebs, H.A.: Metabolic activities of the isolated perfused rat kidney. Biochem. J. 103, 852-862 (1967)

21. Nitzan, M., Metzger, B.E., Wilber, J.F.: The effects of acute uremia on plasma glucose, insulin, and growth hormone in the rat. Life Sci. 10, (Part II), $671-676$ (1971)

22. Owen, O.E., Felig, P., Morgan, A.P., Wahren, J., Cahill Jr., G.F.: Liver and kidney metabolism during prolonged starvation. J. clin, Invest. 48, 574-583 (1969) 
23. Popovic, V., Popovic, P.: Permanent cannulation of aorta and vena cava in rats and ground squirrels. J. appl. Physiol. 15, 727 - 728 (1960)

24. Rabkin, R., Colwell, J.A.: The renal uptake and excretion of insulin in the dog. J. Lab. clin. Med. 73, $893-900$ (1969)

25. Rabkin, R., Simon, N.M., Steiner, S., Colwell, J.A.: Effect of renal disease on renal uptake and excretion of insulin in man. New Engl. J. Med. 282, 182-187 (1970)

26. Reinecke, R.M.: The kidney as a source of glucose in the eviscerated rat. Amer. J. Physiol. 140, 276$285(1943)$

27. Robinson, B.H.B., Wright, P.H.: Guinea-pig antiinsulin serum. J. Physiol. (Paris) 155, 302-310 (1961)

28. Rodriguez-Minon, J.L., Jimenez-Diaz, C.: Las modificaciones del deposito hidrocarbonado del higado por la nefrectomia. Rev. clin. esp. 43, 94-96 (1951)

29. Roxe, D.M.: Renal gluconeogenesis after $\mathrm{NH}_{4} \mathrm{Cl}$, $\mathrm{NaHCO}_{3}$, hypoglycemia or pregnancy. Amer. J. Physiol. 222, 55-60 (1972)

30. Roxe, D.M., Disalvo, J., Balagura-Baruch, S.: Renal glucose production in the intact dog. Amer. J. Physiol. 218, 1676-1681 (1970).

31. Rubenstein, A.H., Spitz, I.: Role of the kidney in insulin metabolism and excretion. Diabetes 17, 161169 (1968)
32. Smith, O.K., Long, C.N.H.: Renal gluconeogenesis in eviscerated diabetic rats. Proc. nat. Acad. Sci. (Wash.) 68, 1618-1622 (1971)

33. Swenson, R.S., Silvers, A., Peterson, D.T., Kohatsu, S., Reaven, G.M. : Effect of nephrectomy and acute uremia on plasma insulin ${ }^{125}$ I-removal rate. J. Lab. clin. Med. 77, 829-837 (1971)

34. Tchobroutsky, G., Collin de l'Hortet, G., Rosselin, G., Assan, R., Derot, M. : Etude de la glycorégulation dans l'insuffisance rénale chronique I. Diabetologia 1, 101-108 (1965)

35. Williamson, J.R.: Effects of fatty acids, glucagon and anti-insulin serum on the control of gluconeogenesis and ketogenesis in rat liver. Adv. Enzyme Regul. 5, 229-255 (1967)

36. Wright, P.H., Makulu, D.R., Posey, I.J.: Guinea pig anti-insulin serum. Adjuvant effect of $H$. pertussis vaccine. Diabetes 17, 513-516 (1968)

Prof. G. Peters Institut de Pharmacologie de l'Université de Lausanne Rue du Bugnon 21 CH-1011 Lausanne Switzerland 